\title{
Patophysiology of articular cartilage in elderly
}

\author{
G Maccauro*, N Gangemi, B Rossi, C Graci, C Fabbriciani \\ From de Senectute: Age and Health Forum \\ Catanzaro, Italy. 5-7 December 2009
}

\section{Background}

Osteoarthritis is a degenerative disease involving diarthrosis articulations. The evolution of the disease is very slow; the first changes regard the cell- matrix morpho-functional unit of articular cartilage called chondron by Benninghoff. The articular cartilage modifications are progressive from the superficial layer through the intermedial and the deep layer.

Authors analyzed the ultrastructural changes of articular cartilage in the elderly, step by step from chondron modifications to macroscopic degenerative changes of the arthrosis.

\section{Materials and methods}

The Authors analyzed knee cartilage from 8 patients with primary osteoarthritis retrieved during TKR procedures. Patients were 5 female and 3 men (age ranging from 57 to 74 years). Preparation of the specimens was made taking cartilage from well conserved areas and from macroscopically degenerated areas. Tissue membrane collected at the time of surgery was fixed in a $10 \%$ neutral buffered formalin, decalcified in ethylenediaminetetracetate (EDTA), dehydrated and embedded in paraffin, sectioned and stained with hematoxilineosine and Gomori-Halmi stains.

For scanning electron microscopy (SEM) samples of cartilage tissues were covered with colloidal palladium, stuck onto a metal support and observed by SEM (Philips SEM 515).

\section{Results}

At the beginning of degeneration, SEM showed articular cartilage modifications in the collagen network surrounding chondrons, especially in the superficial layer, due to metalloproteinase activation; then cracks appeared from the superficial to deep layer. The orientation of these cracks was similar to the one of collagen fibres, and so parallel in the superficial, oblique in the

Orthopaedic Department, Catholic University, Rome, Italy

intermedial and perpendicular in the deep layer. Chondrons appeared empty in the superficial and intermediate layer, even if sometimes some cells were visible in the capsule. The deep layer on the contrary appeared full of chondrons containing many cells. This cell proliferation may be considered an answer to growth factors activation that induces cell mitogenesis and migration in the deep layer. Scanning electron microscopy of anterior cruciate ligaments showed the loosening of transverse interconnecting ligament fibres; intermediate meniscus layer leading to transverse lesions loosened during osteoarthrosis.

\section{Conclusions}

This study confirmed that electron microscopy is a good system in analysing the beginning and the evolution of articular cartilage damage leading to osteoarthritis.

Published: 19 May 2010

doi:10.1186/1471-2318-10-S1-A65

Cite this article as: Maccauro et al.: Patophysiology of articular cartilage in elderly. BMC Geriatrics 2010 10(Suppl 1):A65.

\section{Submit your next manuscript to BioMed Central and take full advantage of: \\ - Convenient online submission \\ - Thorough peer review \\ - No space constraints or color figure charges \\ - Immediate publication on acceptance \\ - Inclusion in PubMed, CAS, Scopus and Google Scholar \\ - Research which is freely available for redistribution

